\title{
Effects of Pre and Post Marination Aging on Quality of Meat
}

\author{
Shahiryar Khalid ${ }^{1}$, Muhammad Bilal Akram ${ }^{1}$, Muhammad Issa Khan ${ }^{2 *}$, Zartasha Siddique ${ }^{1}$, Muhammad Shoaib ${ }^{3}$ \\ ${ }^{1}$ Student, National Institute of food science and Technology, Faculty of Food Nutrition and Home Science, University of \\ Agriculture, Faisalabad, Pakistan \\ ${ }^{2}$ Associate Professor, National Institute of food science and Technology, Faculty of Food Nutrition and Home Science, \\ University of Agriculture, Faisalabad, Pakistan \\ ${ }^{3}$ Student, Institute of Microbiology, University of Agriculture, Faisalabad, Pakistan
}

\begin{abstract}
*Address for Correspondence: Dr. Muhammad Issa Khan, Associate Professor, National Institute of Food Science and Technology, Faculty of Food Nutrition and Home Science, University of Agriculture, Faisalabad, Pakistan
\end{abstract}

E-mail: drkhan@uaf.edu.pk

Received: 16 Sep 2018/ Revised: 26 Nov 2018/ Accepted: 21 Dec 2018

\begin{abstract}
Background: Meat is an animal flesh that is considered best diet for consumption as it comprises vitamins, minerals, basic amino acids and essential fatty acids. World's meat production in 2016 was about 321 million tons. Awareness regarding health and diet increases as meat is a high source of protein, vitamins, minerals and some essential compounds.

Methods: Present study was designed to check the effect of pre and post marinated vacuumed aged beef meat quality at National Institute of Food Science and Technology. The main objectives of this study were to check the effect of pre and post marination aging meat and its acceptability. Round portion of beef meat was firstly pre-marinated with sodium chloride and sodium tri-polyphosphate salts and then subjected to aging for 3 and 7 days at $4^{\circ} \mathrm{C}$. Similarly beef meats were post-marinated vacuumed aged for 3 and 7 days and then this aged meat were marinated with respective salts and compared these treatments with control. Results: The quality assessment for $\mathrm{pH}$, texture, color, WHC, protein solubility were found to be varying significantly as aging along with marination has direct influence with these parameters. Pre and post marinated meat showed non-significant effect for cooking because application of marination cause decrease in cooking loss. Sensory evaluation of aged beef was more acceptable as compared to raw beef meat.

Conclusion: Pre and post-marinated aging has direct relation to the quality parameters of meat. In future, Pre and post marination is a good adaptive method for commercializing the meat products as consumers pay a great attention for quality, safety and high flavored meat and meat products.
\end{abstract}

Key-words: Aging, Beef round cut, Marination, Quality analysis, Sensory evaluation

\section{INTRODUCTION}

Meat is an animal flesh that is eaten for its valuable protein and micronutrients. World's meat production in 2016 was about 321 million tons ${ }^{[1]}$. Palatability of meat attributed by significant key factors like tenderness, juiciness, color, flavor and aroma with regards to Consumer's satisfaction as tenderness being the most significance factor ${ }^{[2]}$. Awareness regarding health and

\section{How to cite this article}

Khalid S, Akram MB, Khan MI, Siddique Z, Shoaib M. Effects of Pre and Post Marination Aging on Quality of Meat. SSR Inst. Int. J. Life. Sci., 2019; 5(1): 2176-2183.

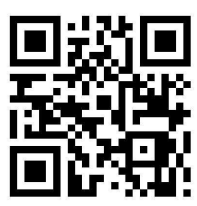

diet increases as meat is a high source of protein, vitamins, minerals and some essential compounds like carnitine, linoleic acid, and carnosine etc ${ }^{[3]}$. People prefer marinated and aged meat from few decades. Tenderness and flavor are the main factors that affect consumer's acceptability and satisfaction. Meat palatability and consumer satisfaction is largely depends upon flavor as meat contain about hundreds of compound that directly or indirectly have role for production of flavor and aroma ${ }^{[4]}$. Marination is a process of soaking meat cuts into a seasoned of salts, herbs, spices, often acidic or liquid for few time before cooking. Tenderness, juiciness, flavor, color and cooking yield is largely enhanced by the use of marination. Meat spoilage could be due to microbes that effect freshness and different metabolic activities that cause off-flavoring 
and off-ordering of meat ${ }^{[5]}$. Salts and sugars are the key components of marination and the most suitable ones are sodium chloride, sugars and polyphosphates. Commonly sea salt and sodium tri-polyphosphate are used for marination. When salt and phosphate used in combination form, it enhances meat flavor, water holding capacity, microstructure of muscles and salt-soluble proteins ${ }^{[6]}$. Phosphate improves waterholding capacity by increasing the meat $\mathrm{pH}$ and unfolding muscle proteins ${ }^{[7]}$. This process of marination causes reduction in the enzymatic as well as bacterial action which extend the shelf-life of meat ${ }^{[8]}$. It is most familiar that tenderness and flavor of meat (especially beef) can be enhanced by storing it for $2-3$ weeks at refrigeration temperature that is $2-4^{\circ} \mathrm{C}{ }^{[9]}$. Stated aging is normally done at $0-4^{\circ} \mathrm{C}$ and 65 to $85 \%$ relative humidity because temperature is suitable for its biochemical changes after post-slaughter rigor mortis. After rigor mortis biochemical changes cause toughness of meat that is due to main enzymes calpain, cathepsins and to some extent due to the action of calcium in the muscles ${ }^{[10]}$. Time and temperature have major influence to improve tenderness of meat ${ }^{[11]}$. Aging time is directly proportion to the rate of lipid oxidation as the time of aging increased rate of lipid oxidation also increases. Increase in aging time causes a decrease in post-mortem $\mathrm{pH}$. On the other hand if aging time is too high, it causes off flavoring of compounds. This is due to the presence of unsaturated fatty acids ${ }^{[12]}$. Result of marinated meat with separate solutions of Calcium lactate $(0.2 \mathrm{M})$ phosphate and salt ( $8.4 \%$ and $4.2 \%$, respectively) can improve water-binding ability and palatability traits ${ }^{[13]}$. These results indicated that the tenderization of beef samples by using a citrus juice marinade could be attributed to muscle proteins uptake and also to solubilization of collagen ${ }^{[14]}$. Soy sauce or red wine marinades can evidently control microbial spoilage as well as oxidation of meat ${ }^{[5]}$ hence, the aim of this study was to access the impact of pre and post marinated aged meat on quality and acceptability with regard to consumer point of view.

\section{MATERIALS AND METHODS}

Procurement of raw material- Round portion of beef meat for research purpose was procured from local market and transported to the Meat Science and Technology Laboratory at National Institute of Food
Science and Technology in University of Agriculture, Faisalabad, Pakistan March to November 2018 for analytical study, while chemicals and reagents were purchased from local distributers of Sigma Aldrich and Fluke, Germany.

Chemical analysis of raw meat- Moisture content, crude (Fat, protein and ash) of beef meat were evaluated according to their respective method described by AOAC [15].

Samples preparation for aging and marinationMarination mixture was prepared by mixing $2.5 \%$ sodium chloride and $2 \%$ sodium tri-polyphosphate. The marination mixture was placed for 24 hours at refrigeration temperature of $4^{\circ} \mathrm{C}$ and then applied to our meat sample. These meat samples were treated according to the treatment plan in which $T_{0}$ is taken as control and $T_{1}$ and $T_{2}$ were firstly marinated and then placed in refrigerator $\left(4^{\circ} \mathrm{C}\right)$ for 3 days and 7 days aging respectively. $T_{3}$ and $T_{4}$ treatments were firstly aged at $4^{\circ} \mathrm{C}$ for 3 days and 7 days and then marination was done.

pH measurement- Meat pH was determined by using digital $\mathrm{pH}$ meter (by following the analytical method described by Sousa et al. ${ }^{[16]}$. The $\mathrm{pH}$ meter was calibrated by using standard $\mathrm{pH}$ buffers of 4 and 7. Take $10 \mathrm{~g}$ minced meat sample and add $90 \mathrm{ml}$ distilled water by using homogenization is done for about 30s at high speed homogenization and centrifuged it at (2665 g) for $10 \mathrm{~min}$ and filtered it. Then filtered sample was placed in a beaker and electrode of $\mathrm{pH}$ meter was placed to check the $\mathrm{pH}$ of required samples.

Texture analysis- Texture profile of meats (marinated as well as un-marinated) sample were determined by texture analyzer as described by Carlos et al. ${ }^{[17]}$. Meat samples were placed on base of the texture analyzer under needle like probe. The force was applied in unit of kilogram. $1.2 \mathrm{~mm}$ thickness of needle like probe was used at the speed of $80 \mathrm{~mm} / \mathrm{min}$. The required value was obtained in the form of graph and force.

Color analysis- Color analysis of meat samples was determined by using colorimeter discussed by Carlos et al. ${ }^{[17]}$. Color value of meat sample was determined by placing the sample under photocell of colorimeter. Colorimeter gives us the values of $L^{*}$ (lightness), $a^{*}$ (redness) and b* (yellowness). 
Water holding capacity (WHC)- WHC was determined by using the method of Chiavaro et al. ${ }^{[18]}$. Total $15 \mathrm{~g}$ minced meat sample was immersed in the $22.5 \mathrm{ml}$ of $0.6 \mathrm{M} \mathrm{NaCl}$ solution. Stir the sample for approximately about $1 \mathrm{~min}$ and allow the mixture to stand for $15 \mathrm{~min}$. Then stir again and centrifuge the solution at $10000 \mathrm{rpm}$ at $4^{\circ} \mathrm{C}$ for $15 \mathrm{~min}$ temperature. Water holding capacity was measure by taking supernatant and put the volume of supernatant into formula to determined final value in percentage

Protein solubility- The solubility of protein was determined by electrophoresis method Mudalal et al. ${ }^{[19]}$. Protein solubility was estimated by the difference in protein extractability and their ionic strength solutions. 1 gram sample was used for protein extraction by using 20 $\mathrm{ml}$ chilled $0.1 \mathrm{M}$ potassium phosphate buffer with $\mathrm{pH}$ of 7.2 and $1.1 \mathrm{M}$ potassium iodide solution respectively. After that, respective buffer solution was used for homogenization of minced meat sample and placed at $4^{\circ} \mathrm{C}$ for overnight. Centrifugation of sample was done at $2600 \times \mathrm{g}$ for $30 \mathrm{~min}$ at $4^{\circ} \mathrm{C}$ and supernatant were discarded and sediments were collected afterthat protein concentrations were measured using biuret method.

\section{Sodium dodecyl sulphate polyacrylamide gel-} electrophoresis- Selected beef protein samples were separated through SDS-PAGE according to their molecular weight Mudalal et al. ${ }^{[19]}$. Marinated and un-marinated aged beef loin meat samples of $4 \mathrm{~g}$ were homogenized with $30 \mathrm{~mL} \mathrm{M}$ phosphate buffer $(\mathrm{pH} 7.4)$ using tissue homogenizer for shorter period of $30 \mathrm{~s}$ time. After that, centrifugation was done of this homogenized mixture at $10,000 \mathrm{~g}$ for approximately 15 to 20 minutes at $4^{\circ} \mathrm{C}$. The resultant supernatant was separated as sarcoplasmic extraction and the resultant pellet was used for myofibrillar protein. These myofibril pellets were dissolved in $40 \mathrm{ml}$ of $0.01 \mathrm{~N}$ phosphate buffers $(\mathrm{pH}$ 6.5) and centrifuged at $10,000 \mathrm{~g}$ at $4^{\circ} \mathrm{C}$ for $20 \mathrm{~min}$. After that supernatant was discarded and the sediments was washed three times with $0.01 \mathrm{~N}$ phosphate buffer and dissolved in $0.03 \mathrm{~N}$ phosphate buffer $(\mathrm{pH}$ 6.5) that contained $0.7 \mathrm{M}$ potassium iodide and $0.02 \% \mathrm{NaN}_{3}$ with liquid/solid ratio of nine. Both these extracted proteins were filtered through a filter paper of $0.45 \mu \mathrm{m}$ and concentration of protein was positioned at $1 \mathrm{mg} / \mathrm{ml}$ through biuret method for determination of protein.
Sodium dodecyl sulphate poly acrylamide gel electrophoresis was performed by the method described by Mudalal et al. ${ }^{[19]}$. They used separation gel (7.5\%) and stacking gel (4\%). One $\mathrm{mg}$ protein $/ \mathrm{ml}$ sample was mixed with $0.19 \mathrm{ml}$ of Laemmli buffer and $1 \mu$ l of mercaptoethanol, $0.2 \mathrm{ml}$ sample and molecular weight standard of protein (25-250 kDa) were loaded onto gel and electrophoresis was run and conducted at $220 \mathrm{~V}$ for 150 min. Coomassie Brilliant blue R-250 gel was stained and scanned after detaining. Total proteins were estimated with respect to their molecular weight and by their relative affinities.

Cooking loss- Cooking loss of meat sample was determined by Chung et al. ${ }^{[20]}$. Take $20 \mathrm{~g}$ meat sample and placed in a polythene bag. Heat the sample at 80 $90^{\circ} \mathrm{C}$ in water bath so that meat's internal temperature should be reached to $72^{\circ} \mathrm{C}$. After cooking, water was drained out and residue was cooled at room temperature and weighted. Put the calculated value in formula and get the percentage value.

TBARS assay- Thiobarbituric acid reactive substances (TBARS) of beef meat were determined by the following method described by Istrati et al. ${ }^{[21]}$. Five $g$ of minced meat sample was placed it in $15 \mathrm{ml}$ distilled water. Homogenized the sample at high speed homogenizer at speed of $16000 \mathrm{rpm}$ for 15 to $20 \mathrm{sec}$. Filtration was done by using filter paper. Add $50 \mu \mathrm{l}$ BHT solution was added with the help of micropipette. One $\mathrm{ml}$ of homogenate was added with $2 \mathrm{ml} \mathrm{TBA/TCA}$ solution. Test tube was heated in water bath at $90^{\circ} \mathrm{C}$ for $30 \mathrm{~min}$. after cooling sample was placed for centrifugation at $3000 \mathrm{rpm}$ for 10 min. Two $\mathrm{ml}$ supernatant was taken with the help of pipette and their absorbance was recorded at $532 \mathrm{~nm}$ using distilled water as blank in UV-VIS spectrophotometer.

Sensory evaluation of marinated meat- Sensory evaluation of grilled meat products was carried out by trained panel of judges with the help of 9 point Hedonic scale ${ }^{[22]}$.

Statistical Analysis- The data obtained from each parameter was statistically analyzed and subjected to complete randomization design (CRD) to interpret the level of significance as described by Meilgaard et al. ${ }^{[23]}$ using the statistic 10.0 software. 


\section{RESULTS}

Our result of proximate analysis for beef meat was shows in Table 1. Quality analysis of beef meat was done to check the affect the pre and post marination on meat, for this quality analysis was done in which $\mathrm{pH}$ and texture analysis of beef meat was done that shown in Table 2. Where, $T_{0}=$ Control, $T_{1}=$ Marination + Aging (3 days), $T_{2}=$ Marination + Aging $\left(7\right.$ days), $T_{3}=$ Aging ( 3 days)

+ Marination, $T_{4}=$ Aging (7 days) + Marination. In Table 3 mean value of raw and treated beef was showed the check the quality analysis. TBARS value and protein solubility in Table 4 and Table 5 water holding capacity of beef meat was done by using cooking loss method and by drip loss method to checked the quality. Sensory evaluation of pre and post marination of meat was done to understand the quality attributes by a panel list by using a hedonic scale.

Table 1: Mean Values of Proximate analysis for beef meat

\begin{tabular}{ccccc}
\hline Sample & Moisture \% & Protein \% & Fat \% & Ash \% \\
\hline Raw Beef & $73.63 \pm 0.96^{\mathrm{a}}$ & $21.50 \pm 4.40^{\mathrm{b}}$ & $3.95 \pm 0.49^{\mathrm{c}}$ & $1.13 \pm 0.07^{\mathrm{c}}$ \\
\hline
\end{tabular}

Table 2: Mean Values for $\mathrm{pH}$ and Texture analysis of Raw and Treated Meat

\begin{tabular}{cccccc}
\hline Analysis & $\mathbf{T}_{\mathbf{0}}$ & $\mathbf{T}_{\mathbf{1}}$ & $\mathbf{T}_{\mathbf{2}}$ & $\mathbf{T}_{\mathbf{3}}$ & $\mathbf{T}_{\mathbf{4}}$ \\
\hline $\mathbf{p H}$ & $6.00 \pm 0.10$ & $6.27 \pm 0.22$ & $6.45 \pm 0.04$ & $6.28 \pm 0.30$ & $6.22 \pm 0.11$ \\
Tex. value & $5.10 \pm 0.10$ & $5.30 \pm 0.05$ & $5.80 \pm 0.10$ & $5.33 \pm 0.06$ & $5.33 \pm 0.06$
\end{tabular}

Where, $T_{0}=$ Control, $T_{1}=$ Marination + Aging (3 days), $T_{2}=$ Marination + Aging $(7$ days $), T_{3}=$ Aging (3 days $)+$ Marination, $T_{4}=$ Aging $(7$ days $)+$ Marination

Table 3: Mean values for colour analysis of Raw and Treated Meat

$\begin{array}{llllll}\text { Analysis } & \mathrm{T}_{0} & \mathrm{~T}_{1} & \mathrm{~T}_{2} & \mathrm{~T}_{3} & \mathrm{~T}_{4}\end{array}$

\section{Color analysis}

$\begin{array}{lrrrrr}\text { L* }^{*} & 40.88 & 43.46 & 42.25 & 43.68 & 41.48 \\ \text { a* } & 9.00 & 8.18 & 9.67 & 10.53 & 8.75 \\ \text { b* } & -2.34 & -1.61 & 0.53 & 0.31 & -1.52\end{array}$

Where, $T_{0}=$ Control, $T_{1}=$ Marination + Aging (3 days), $T_{2}=$ Marination + Aging $(7$ days $), T_{3}=$ Aging (3 days) + Marination, $T_{4}=$ Aging $(7$ days $)+$ Marination

Table 4: Mean values for protein solubility and TBARS of Raw and Treated Meat

\begin{tabular}{cccccc}
\hline Analysis & $\mathbf{T}_{\mathbf{0}}$ & $\mathbf{T}_{\mathbf{1}}$ & $\mathbf{T}_{\mathbf{2}}$ & $\mathbf{T}_{\mathbf{3}}$ & $\mathbf{T}_{\mathbf{4}}$ \\
\hline TBARS & $0.28 \pm .04$ & $0.27 \pm .04$ & $0.31 x \pm .02$ & $0.32 \pm .04$ & $0.34 \pm .04$ \\
$\begin{array}{c}\text { Protein } \\
\text { solubility }\end{array}$ & $7.70 \pm .02$ & $7.45 \pm .02$ & $9.03 \pm .02$ & $8.17 x \pm .02$ & $10.26 \pm .02$ \\
\hline
\end{tabular}

Where, $T_{0}=$ Control, $T_{1}=$ Marination + Aging (3 days), $T_{2}=$ Marination + Aging (7 days), $T_{3}=$ Aging (3 days) + Marination, $T_{4}=$ Aging $(7$ days $)+$ Marination 
Table 5: Mean values for cooking loss and water holding capacity of Raw and Treated meat

\begin{tabular}{|c|c|c|c|c|c|}
\hline Analysis & $T_{0}$ & $\mathrm{~T}_{1}$ & $\mathbf{T}_{2}$ & $T_{3}$ & $\mathbf{T}_{4}$ \\
\hline Cooking loss (\%) & $34.59 \pm .55$ & $43.83 \pm .25$ & $43.77 \pm .23$ & $36.99 \pm .01$ & $34.71 \pm .23$ \\
\hline WHC (\%) & $59.00 \pm 2.65$ & $62.00 \pm 3.29$ & $68.33 \pm 3.28$ & $70.33 \pm 1.53$ & $76.00 \pm 2.61$ \\
\hline
\end{tabular}

Where, $T_{0}=$ Control, $T_{1}=$ Marination + Aging (3 days), $T_{2}=$ Marination + Aging $(7$ days $), T_{3}=$ Aging (3 days) + Marination, $T_{4}=$ Aging $(7$ days $)+$ Marination

Table 6: Mean values for sensory evaluation of Raw and Treated meat

\begin{tabular}{cccccc}
\hline Sensory eva. & $\mathbf{T}_{\mathbf{0}}$ & $\mathbf{T}_{\mathbf{1}}$ & $\mathbf{T}_{\mathbf{2}}$ & $\mathbf{T}_{\mathbf{3}}$ & $\mathbf{T}_{\mathbf{4}}$ \\
\hline Appearance & $6.40 \pm .02$ & $7.20 \pm .04$ & $6.60 \pm .03$ & $8.20 \pm .02$ & $8.00 \pm .01$ \\
Flavour & $5.20 \pm .03$ & $6.40 \pm .05$ & $6.60 \pm .04$ & $8.20 \pm .02$ & $7.80 \pm .04$ \\
Texture & $5.20 \pm .05$ & $6.40 \pm .06$ & $6.60 \pm .06$ & $8.20 \pm .08$ & $7.80 \pm .07$ \\
Juiciness & $5.20 \pm .01$ & $6.60 \pm .03$ & $6.20 \pm .02$ & $8.60 \pm .05$ & $8.80 \pm .06$ \\
Overall acceptability & $5.40 \pm .02$ & $7.00 \pm .05$ & $6.60 \pm .04$ & $8.00 \pm .07$ & $8.20 \pm .06$ \\
\hline
\end{tabular}

\section{DISCUSSION}

Normally animal flesh contain nearly all essential components that builds up our muscles as well as required by our body for proper growth and development i.e. water content in meat, protein content, fat content and micronutrients that's why meat is an essential source of quality and valuable protein Pereira et al. ${ }^{[24]}$. Mean values for proximate analysis of raw beef meat were given in Table 1 . Total content (\%) of proximate analysis (moisture, protein, fat and ash) of raw beef (round cut) was found to $73.63 \pm 0.96$, $21.50 \pm 4.40,3.95 \pm 0.49$, and $1.13 \pm 0.07$ respectively. Our finding of proximate analysis of beef cut except fat was supported by the Goklap et al. ${ }^{[25]}$. Just minor variations were seen in fat values. Fat that is present in inner muscles and intra muscles of beef portions have high value of nutritious profile Lawrie et al. ${ }^{[26]}$. Variations in the results among all treatment were highly significant. Meat muscles (round cut) were further analyzed for its quality test. Sodium chloride and sodium tri polyphosphate based marinades are categorized as alkaline based marinades that results in an increased in muscle $\mathrm{pH}$ of beef. Our findings are in line with the study of scientist Se et al. ${ }^{[27]}$, who were reported that production of lactic acid slows down as marinations of salts applied. It is obvious from the mean values that $\mathrm{pH}$ of beef muscles varied significantly from 6.00 to 6.45 among all treatments respectively. The mean value for $T_{4}$ has nearest value to control treatment and $T_{2}$ has maximum deviated value from the control because of application of marination for 7 days. Texture is the main component for acceptability of meat product. Mean value of texture for raw, aged and marinated meat has been illustrated in Table 2, which shows that force applied varied from 5.10 to $5.80 \mathrm{~kg}$ among all treatments. The maximum force applied was observed for $T_{2}$ treatment with marination for 7 days while the minimum force was recorded for $\mathrm{T}_{0}$ (control). Tenderness increased with increase in ain and marination that directly affect the shear force. The data regarding this study was identical to the results depicted by Nikmaram et al. ${ }^{[28]}$. Color is the most important factor for consumer appeal. Consumer like and get meat according to the color display. If meat's colour is not bright and red consumers assume that require meat is poor with respect to quality standards Young et al. ${ }^{[29]}$. Color stability has direct influence with redox reaction by difference in their post-mortem $\mathrm{pH}$ and temperature ${ }^{[30]}$. Bright red color of fresh meat is due to the presence of oxymyoglobin as a result of reaction between myoglobin and oxygen. Discoloration of meat is because of less presence of oxygen in meat muscles Sammel et al. ${ }^{[30]}$. 
Three different types of colors were determined by placing the sample under photocell of colorimeter. The mean value of $L^{*} a^{*} b^{*}$ for color of meat obtained are in range from 40.88 to 43.68 for $L^{*}, 8.18$ to 10.53 for $a^{*}$, 2.34 to 0.53 for $b^{*}$ respectively. Florek et al. ${ }^{[31]}$ were observed the relationship among color and aging time on different meat cuts and investigated that $L^{*}, a^{*}$ and $b^{*}$ values increases as the post-mortem aging time increases. Protein solubility increases with the increase in their aging and marination because aging and marination both cause degradation of protein with due to enzymatic action and chance in $\mathrm{pH}$ concentration Hrynets et al. ${ }^{[32]}$. It was observed from the data depicted in 4.4 that the protein solubility significantly varied from 7.45 to 10.26 . The highest value for protein solubility has been noted as 10.26 for treatment $T_{4}$ while the lowest value for protein solubility was observed for $T_{1}$. Higher weight sarcoplasmic protein showed separation and appearance of new bands which creates lower molecular weight protein Cooking loss is actually the loss of water from the outer surface of meat that is expelled out by applying heat treatment. The findings of present study illustrated that varies range of meat for cooking loss among different treatments from 34.59 to $43.83 \%$. Highest amount of cooking losses was observed in $T_{1}$ while $T_{0}$ shows lowest amount of cooking loss. It was evident from the data that cooking loss among treatments was non-significant. The result of present study was congruent with the finding of Aaslyng et al. ${ }^{[33]}$. They reported that cooking loss can also be related to $\mathrm{pH}$ of meat, with decrease in $\mathrm{pH}$ the cooking loss increases. Water holding capacity is capacity of meat to hold the water content when external force is applied on it such as cutting, mincing and heating. WHC directly or indirectly affects the appearance of meat including its tenderness, flavor, juiciness and amount of purchasing the meat ${ }^{[34]}$. WHC affected by aging and marination process. During aging, cells of meat shrinks and degradation of protein filaments cause changes the property of water binding abilities and its distribution Huff and Lonergan ${ }^{[35]}$. Water holding capacity of meat was decreased as the concentration of salt increased in brine solution which degrades the protein and increased water loss ${ }^{[18]}$. The data regarding the mean values of beef meat given in Table 5, the values of WHC ranges between 59 to $76(\%)$ for $\mathrm{T}_{4}$ (aging 7 days + marination) showed maximum water holding capacity while minimum $W H C$ observed in $T_{0}$. The finding of research investigation found similar with the results of previous research Huff et al. ${ }^{[35]}$. Oxidation of lipid in meat cause degradation of muscles which results in the production of different compounds like (ketones and aldehyde) that creates thiobarbituric reactive substances AOAC ${ }^{[15]}$. TBARS value is an indicator of oxidation of fatty compounds present in beef meat Raharjo et al. ${ }^{[36]}$. Sensory evaluation for pre and post marinated aged meat product was analyzed. Different factors were determined during sensory evaluation was (Flavor, appearance, texture, juiciness, and overall acceptability) that showed significant. By sensory evaluation, T4 treatment shows best result regarding overall acceptability.

\section{CONCLUSIONS}

Pre and post-marinated aging has direct relation to the quality parameters of meat. Aging and marination has a significant impact on protein solubility, $\mathrm{pH}, \mathrm{WHC}$, texture and color properties of meat values that further increase the tenderization to meat and meat products. Pre and post-Marination (Sodium chloride and sodium tripolyphosphate) enhances the flavor and color properties of meat. Aging of meat with salts reduces the oxidation of meat and enhance the overall acceptability. In future, Pre and post marination can be a good adaptive method for commercializing the meat products as consumers pay a great attention for quality, safety and high flavored meat and meat products.

\section{ACKNOWLEDGMENTS}

The authors are grateful to Associate Professor Dr. Muhammad Issa Khan for valuable comments to the manuscript.

\section{CONTRIBUTION OF AUTHORS}

Research concept- Muhammad Issa Khan, Shahiryar Khalid

Research design- Muhammad Issa Khan, Shahiryar Khalid Supervision- Muhammad Issa Khan

Materials- Muhammad Issa Khan

Data collection- Shahiryar Khlid, Muhammad Bilal Akram Data analysis- Shahiryar Khlid, Muhammad Bilal Akram

Literature search- Shahiryar Khlid, Muhammad Bilal Akram, Muhammad Shoaib

Writing article- Shahiryar Khlid, Muhammad Bilal Akram Critical review- Muhammad Issa Khan 
Article editing- Muhammad Bilal Akram

Final approval- Muhammad Issa Khan

\section{REFERENCES}

[1] Food and Agriculture Organization (FAO) United Nations. Meat and Meat Products. Animal Production and Health, Rome, Italy, 2016.

[2] Fu Y, Young JF, Therkildsen M. Bioactive peptides in beef: Endogenous generation through postmortem aging. Meat Sci., 2017(1); 123: 134-42.

[3] Arihara K. Strategies for designing novel functional meat products. Meat Sci., 2006; 74(1): 219-29.

[4] Calkins CR, Hodgen JM. A fresh look at meat flavour. Meat Sci., 2007; 77(1): 63-80.

[5] Kargiotou C, Katsanidis E, Rhoades J, Kontominas M, Koutsoumanis $K$. Efficacies of soy sauce and wine base marinades for controlling spoilage of raw beef. Food Microbiol., 2011; 28(1): 158-63.

[6] Tribuzi G, Schmidt FC, Laurindo JB. Operational diagrams for salting-marination processes and quality of cooked mussels. LWT- Food Sci. Technol., 2014; 59(2):746-53.

[7] Yoon KS. Texture and microstructure properties of frozen chicken breast pre-treated with salt and phosphate solutions. Poult. Sci., 2002; 81(12): 1910-15.

[8] Serdaroglu M, Yildiz-Turp G, Abrodimov K. Quality of low-fat meatballs containing legume flours as extenders. Meat Sci., 2005; 70(1): 99-105.

[9] Dashdorj D, Tripathi VK, Cho S, KimY, Hwang I. Dry aging of beef: A review. J. Anim. Sci. Technol., 2016; 58(1): 18-20.

[10]Lida F, Miyazaki Y, Tsuyuki R, Kato K, Egusa A, et al. Changes in taste compounds, breaking properties and sensory attributes during dry aging of beef from Japanese black cattle. Meat Sci., 2016; 112(1): 46-51.

[11]Adegoke F, Falade P. Influence of breed and aging time on the sensory meat quality and consumer acceptability in intensively reared beef. Meat Sci., 2005; 71: 471-79.

[12]Ismail HA, Lee EJ, Ko KE, Ahn DU. Effects of aging time and natural antioxidants on the color, lipid oxidation and volatiles of irradiated ground beef. Meat Sci., 2008; 80(3): 582-91.

[13]Lawrence TE, Dikeman ME, Hunt MC, Kastner CL, Johnson DE. Staged injection marination with calcium lactate, phosphate and salt may improve beef water-binding ability and palatability traits. Meat Sci., 2003; 65(3): 967-72.

[14]Burke RM, Monahan FJ. The tenderization of shin beef using a citrus juice marinade. Meat Sci., 2003; 63(2): 161-68.

[15]AOAC. Official Methods of Analytical Chemist. $18^{\text {th }}$ ed., Gaithersburg, M.D.USA; Association of Official Analytical Chemists: 2011.

[16]Sousa SC, Fragoso SP, Penna CRA, Arcanjo NMO, Silva FAP, et al. Quality parameters of frankfurtertype sausages with partial replacement of fat by hydrolyzed collagen. LWT- Food Sci. Technol., 2017; 76(1): 320-25.

[17]Carlos M L, Mendes RC, Maria LN. Instrumental texture and sensory characteristics of cod frankfurter sausages. Int. J. Food Prop., 2009; 12(3): 625-43.

[18]Chiavaro E, Rinaldi M, Vittadini E, Barbanti D. Cooking of pork Longissimus dorsi cat different temperature and relative humidity values: Effects. Meat Sci., 2009; 93(2): 158-68.

[19]Mudalal S, Babini E, Cavani C, Petracci M. Quantity and functionality of protein fractions inchicken breast fillets affected by white striping. Poult. Sci., 2014; 93(8): 2108-116.

[20]Chung S, Yettella RR, Kim J, Kwon K, Kim M, et al. Effects of grilling and roasting on the levels of polycyclic aromatic hydrocarbons in beef and pork. Food Chem., 2011; 129(4): 1420-26.

[21]Istrati D, Constantin O, lonescu A, Vizireanu C, Dinica R. Study of the combined effect of spices and marination on beef meat vaccum packaged. Food Tech., 2011; 35(2): 75-85.

[22]Meilgaard M, Civille GV, Carr BT. Sensory evaluation techniques. $3^{\text {rd }}$ ed., USA; CRC Press LLC, 2007.

[23]Steel RGD, Torrie JH, Dicky DA. Principles and Procedures of Statistics. A biochemical approach. $3^{\text {rd }}$ ed., New York; McGraw Hill Book Co. Inc: 1997.

[24]Pereira PMDC, Vicente AFDRB. Meat nutritional composition and nutritive role in the human diet: $A$ Review. Meat Sci., 2013; 93(3): 586-92.

[25]Goklap HY, Kaya M, Tulek Y, Zorba O. Laboratory manual for quality control in meat and meat products. Turkish Agriculture College, Food Engineering Department, Turkey, 1993: pp. 117.

[26]Lawrie RA, Leward DA. Lawries Meat Science. $7^{\text {th }}$ ed., Cambridge; Wood head publishing limited: 2006; pp. 195-27. 
[27]Se M, Dastidar MG. Biosorption of $\mathrm{Cr}$ (VI) using fungal strain of Fusarium sp. ASCE, 2005; 9(2): 147-51.

[28]Nikmaram P, Yarmand MS, Emamjomeh Z, Darehabi $H K$. The effect of cooking methods on textural and microstructure properties of veal muscle (Longissimus dorsi). Glob. Vet., 2011; 6: 201-07.

[29]Young OA, Priolo A, Smmons NJ, West J. Effect of rigor attainment temperature on meat blooming and color on display. Meat Sci., 1999; 52(1): 47-56.

[30]Sammel LM, Hunt MC, Kropf DH, Hachmeister KA, Kastner CL, Johnson DC. Influence of chemical characteristics of beef inside and outside emi membrane osuson colour traits. J. Food Sci., 2002; 67(4): 1323-30.

[31]Florek M, Litwinczuk A, Skalecki P, Ryszkowska-Siwko M. Changes of physicochemical properties of bullocks and heifers meat during 14 days of aging under vacuum. Polish. Int. J. Food Sci. Nutr., 2003; 57(3): 281-88.
[32] Hrynets $Y$, Omana DA, Xu Y, Betti M. Comparative study on the effect of acid and alkaline-aided extractions on Mechanically Separated Turkey Meat (MSTM): Chemical and functional properties of recovered proteins. Process Biochem., 2011;4 6(7): 335-43.

[33]Aaslyng MD, Bejerholm C, Ertbjerg P, Bertram HC, Andersen HJ. Cooking loss and juiciness of pork in relation to raw meat quality and cooking procedure. J. Food Quality, 2003; 14(4): 277-88.

[34]Sales J, Horbanczuk J. Ratite meat. Poult. Sci., 1998; 54(1): 59-67.

[35]Huff LE, Lonergan SM. Mechanisms of water-holding capacity of meat: The role of post-mortem biochemical and structural changes. Meat Sci., 2005; 71(1): 194-204.

[36]Raharjo S, Sofos JN. Methodology for measuring malonaldehyde as a product of lipid peroxidation in muscle tissues: A review. Meat Sci., 1993; 35(2): 145-69. 